\title{
ANALISIS ASPEK PASAR DAN PEMASARAN DALAM BERWIRAUSAHA
}

Makalah ini di susun untuk memenuhi tugas dari mata kuliah

Kewirausahan

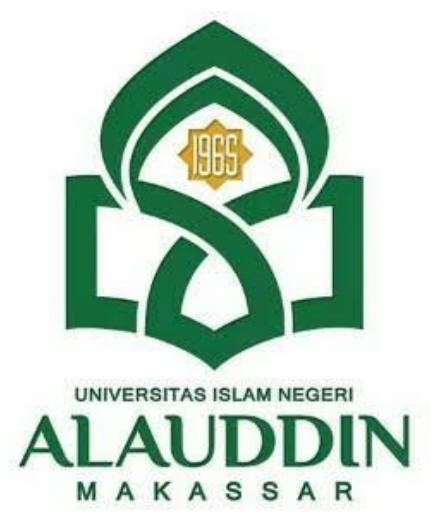

Oleh:

Rahmayani Ahmad

90500120043

rahmayani13112001@gmail.com

PERBANKAN SYARIAH

FAKULTAS EKONOMI DAN BISNIS ISLAM

UIN ALAUDDIN MAKASSAR 


\begin{abstract}
ABSTRACK
Dalam berbisnis atau berwirausaha pemasaran sangat penting dalam menentukan sukses tidaknya sebuah usaha atau bisnis yang di lakukan atau di jalankan. Keberhasilan suatu strategi yang telah ditetapkan sangat ditentukan oleh seberapa besar tingkat kesesuaian strategi tersebut dengan perubahan lingkungan, persaingan, serta situasi perusahaan. Pada akhirnya perencanaan strategi yang meliputi analisis, Seorang pebisnis harus jeli melihat kondisi pasar, mereka harus bisa menganalisa berbagai potensi keuntungan dan dapat memperediksi kerugian apa saja yang bisa terjadi.
\end{abstract}

Kata kunci: pebisnis, pasar, perusahaan, pemasaran 


\section{KATA PENGANTAR}

Segala puji hanya milik Allah SWT. Shalawat dan salam selalu tercurahkan kepada Rasulullah SAW. Berkat limpahan dan rahmatnya penyusun mampu menyelesaikan tugas makalah ini guna memenuhi tugas yang di berikan pada mata kuliah kewirausahaan ini.

Dalam penyusunan makalah, tidak sedikit, hambatan yang penulis hadapi, baik itu yang datang pada penulis maupun yang datang dari luar. Namun penulis menyadarinya bahwa kelancaran dalam penulisan ini tidak lain berkat bantuan, dorongan, dan bimbingan para orang tua, dosen bidang studi yang bersangkutan, dan para sahabat, terutama pertolongan dari Allah sehingga kendala-kendala yang penulis hadapi dapat teratasi.

Makalah ini di susun agar para pembaca dapat memperluas ilmu tentang berbagai aspek hukum yang terdapat pada studi kelayakan bisnis yang kami dapat dari berbagai sumber informasi seperti journal internet, artikel, dan referensi lainnya.

Semoga makalah ini dapat memberikan wawasan yang lebih luas dan menjadi sumbangan pemikiran kepada pembaca. Penulis sadar bahwa makalah ini masih banyak memiliki banyak kekurangan dan jauh dari kata sempurna. Untuk itu, penulis mengharapkan kritik dan saran dari para pembaca demi kebaikan penulis di masa yang akan datang.

Gowa, 16 September 2021

Penulis 


\section{DAFTAR ISI}

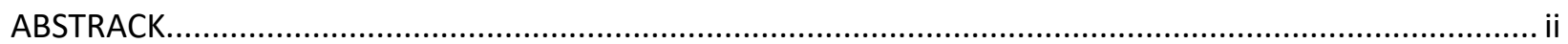

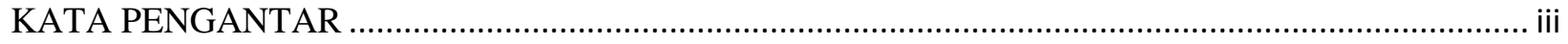

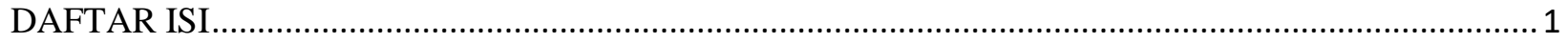

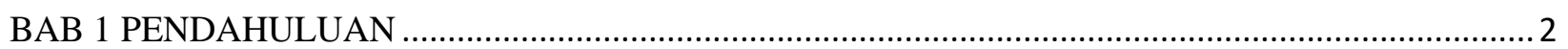

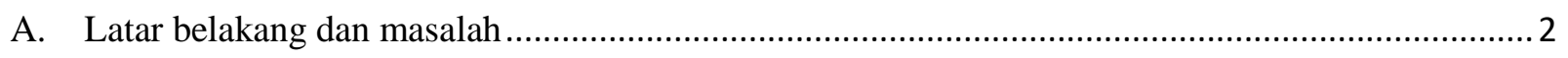

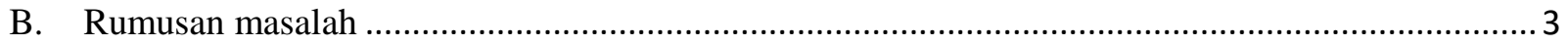

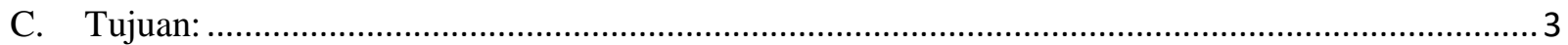

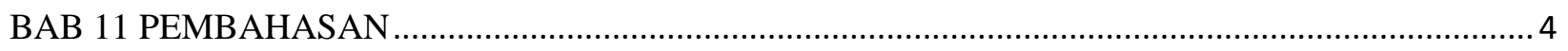

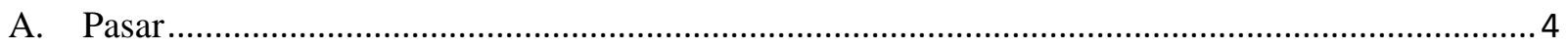

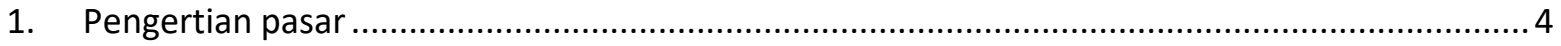

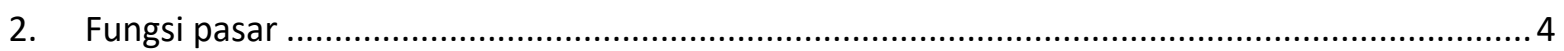

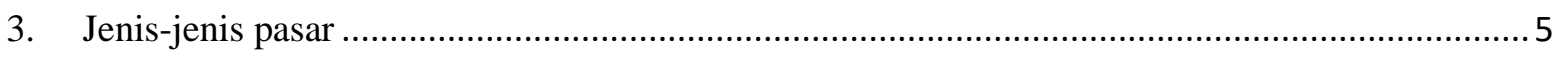

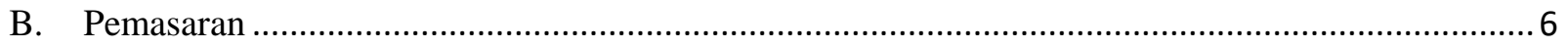

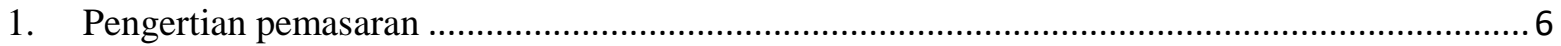

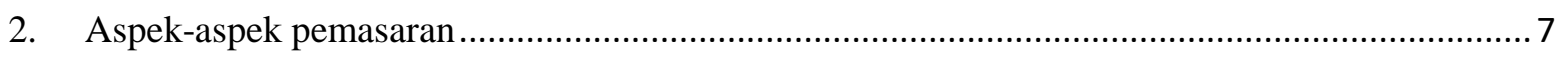

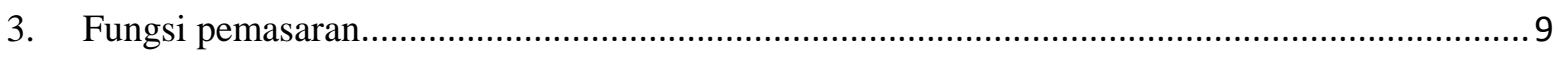

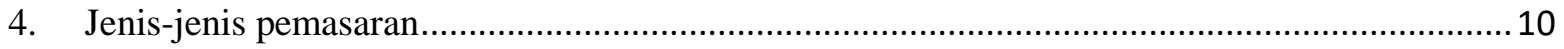

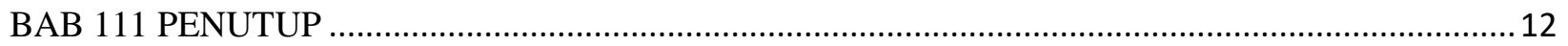

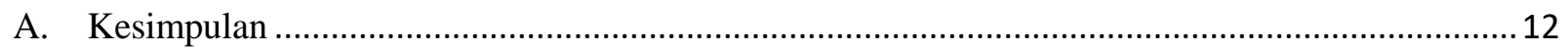

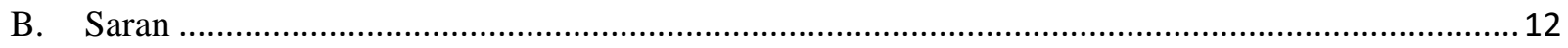

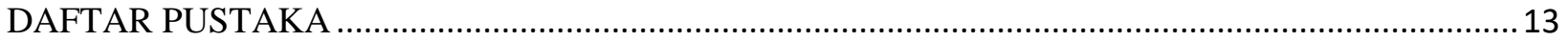




\section{BAB 1 \\ PENDAHULUAN}

A. Latar belakang dan masalah

Pemasaran, dan lebih khusus lagi, orientasi pasar telah diidentifikasi sebagai kontributor penting untuk kinerja usaha (Deshpande et al., 1993; Jaworski dan Kohli, 1993; Narver dan Slater, 1990). Dengan semakin pesatnya penjualan yang ada di Indonesia, menyebabkan terjadinya persaingan yang semakin ketat. Sedangkan disisi lain jumlah permintaan konsumen masih terbatas. Maka fungsi pemasaran menempati proporsi yang semakin menentukan bisnis perusahaan, tentu saja tanpa mengesampingkan fungsi-fungsi bisnis yang lainnya. Pergeseran variabel yang mempunyai persaingan dapat menimbulkan masalah, disaat belum ada persaingan maka perusahaan belum membutuhkan pemasaran, pada saat persaingan semakin keras, maka pemasaran menjadi fungsi yang semakin penting di perusahaan dan pada saat situasi persaingan sudah sangat keras tidak dapat diduga dan kacau, pemasaran menjadi konsep bisnis yang menjiwai setiap orang dalam perusahaan.

Keuntungan utama dari strategi pemasaran yang tidak terdiferensiasi ini adalah terjadinya penghematan biaya produksi, promosi dan distribusi, karena perusahaan hanya menghadapi suatu produk yang standar. Tetapi hams diakui bahwa strategi pemasaran yang tidak terdiferensiasi ini semakin jarang digunakan karena tingkat persaingan yang semakin ketat, meningkatnya kacanggi han dan fragmentasi mayoritas pasar di negaranegara maju.

Keberhasilan suatu strategi yang telah ditetapkan sangat ditentukan oleh seberapa besar tingkat kesesuaian strategi tersebut dengan perubahan lingkungan, persaingan, serta situasi perusahaan. Pada akhirnya perencanaan strategi yang meliputi analisis, 
perumusan, evaluasi sangat membantu perusahaan dalam menetapkan strategi pemasaran yang tepat.

B. Rumusan masalah

1. Apa yang di maksud dengan pasar?

2. Apa fungsi pasar?

3. Apa saja jenis-jenis pasar?

4. Apa yang di maksud dengan aspek pemasaran?

C. Tujuan:

1. Mahasiswa mengetahui apa yang di maksud dengan pasar

2. Dapat mengetahui fungsi pasar

3. Dapat mengetahui jenis-jenis pasar

4. Dapat mengetahui apa yang di maksud dengan aspek pemasaran 


\section{BAB 11 \\ PEMBAHASAN}

A. Pasar

1. Pengertian pasar

Pasar dapat di artikan sebagai tempat bertemunya antara penjual dan pembeli untuk melakukan transaksi. Sedangkan menurut management study guide, pasar merupakan suatu pengaturan di mana dua pihak atau lebih terlibat dalam pertukaran barang, layanan, dan informasi di sebut pasar. Idealnya pasar adalah tempat di mana dua pihak arau lebih terlibat dalam pembelian dan penjualan.

2. Fungsi pasar

Secara umum, pasar sendiri memiliki tiga fungsi utama, yaitu: fungsi distribusi, pembentukan harga, dan fungsi promosi. Berikut penjelasannya:

a. Pasar sebagai sarana distribusi

Pasar sebagai sarana distribusi, berfungsi memperlancar proses penyaluran barang atau jasa dari produsen ke konsumen. Dengan adanya pasar, produsen dapat berhubungan baik secara langsung maupun tidak langsung untuk menawarkan hasil produksinya kepada konsumen.

b. Pasar sebagai pembentuk harga

Pasar merupakan tempat pertemuan antara penjual dan pembeli. Di pasar tersebut penjual menawarkan barang-barang atau jasa kepada pembeli. Pembeli yang membutuhkan barang atau jasa akan berusaha menawarkan harga dari barang atau jasa tersebut, sehingga terjadi tawar menawar antar kedua bela pihak. Setelah terjadi kesepakatan, terbentuklah harga.

c. Pasar sebagai sarana promosi 
Pasar sebagai sarana promosi artinya pasar menjadi tempat memperkenalkan dan menginformasikan suatu barang/ jasa tentang manfaat, keunggulan, kekhasan pada konsumen.

Promosi di lakukan untuk menarik minat konsumen atau pembeli terhadap barang atau jasa yang di perkenalkan.promosi dapat di lakukan dengan berbagai cara antara lain, memasang spanduk, menyebarkan brosur, pameran dan sebagainya.

Menurut sudarman (1989), pasar mempunyai lima fungsi utama yaitu:

a. Pasar menetapkan nilai

Dalam ekonomi pasar, harga merupakan ukuran nilai

b. Pasar mengorganisir produk

Dengan adanya harga-harga factor 9 pasar, maka akan mendorong produsen memilih metode produksi yang efisien

c. Pasar mendistribusikan barang

Kemampuan seseorang dalam membeli barang tergantung pada penghasilan

d. Pasar berfungsi menyelenggarakan penjatahan (rationing)

Penjatahan adalah inti dari adanya harga

e. Pasar mempertahankan dan mempersiapakan keperluan di masa yang akan datang

3. Jenis-jenis pasar

a. Jenis pasar menurut bentuk kegiatannya

a) Pasar nyata 
Pasar nyata adalah pasar di mana barang-barang akan di perjual belikan dan dapat di beli oleh pemebeli.

b) Pasar abstark

Pasar abstarak adalah pasar di mana para pedagangnya tidak menawar barang-barang yang akan di jual dan tidak membeli secara langsung tetapi hanya dengan menggunakan surat dagangnya saja.

b. Jenis pasar menurut cara transaksinya

a) Pasar tradisional

Pasar tradisional adalah pasar yang bersifat tradisional di mana para penjual dan pembeli dapat mengadakan tawar menawar secara langsung. Barang-barang yang di perjual belikan adalah barang yang berupa barang kebutuhan pokok

b) Pasar modern

Pasar modern adalah pasar yang bersifat modern di mana barangbarang di perjual belikan dengan harga pas dan dengan layanan sendiri. Tempat berlangsungnya pasar ini ada di mal, plaza, dan tempat-tempat modern lainnya.

B. Pemasaran

1. Pengertian pemasaran

Defenisi marketing atau pemasaran adalah kegiatan yang di lakukan oleh perusahaan untuk mempromosikan suatu produk atau layanan yang mereka punya. Pemasaran ini mengcangkup pengiklanan, penjualan, dan pengiriman produk kepada ke konsumen atau perusahaan lain. 


\section{Aspek-aspek pemasaran}

a. Segmentasi pasar

Segmentasi pasar merupakan kegiatan membagi suatu pasar menjadi kelompok kelompok pembeli yang berbeda dan membutuhkan produk atau bauran pemasaran yang berbeda. Segementasi pasar juga dapat diartikan sebagai proses pengidentifikasian dan menganalisis para pembeli di pasar produk, menganalisis perbedaan antara pembeli di pasar. Penerapan strategi pemasaran yang tepat dalam menciptakan keunggulan bersaing dan gebrakan-gebrakan baru sangat diperlukan guna tercapainya peningkatan efisiensi dan memperbesar pangsa pasar.

Strategi pemasaran menurut Kotler (2007) adalah sebagai berikut: "Strategi pemasaran adalah logika pemasaran, berdasarkan itu unit bisnis diharapkan mencapai sasaran-sasaran pemasaran. Strategi pemasaran terdiri dari pengambilan keputusan tentang biaya pemasaran dari perusahaan, bauran pemasaran dan alokasi pemasaran dalam hubungannya dengan keadaan lingkungan yang diharapkan dan kondisi persaingan”.

Penentuan strategi pemasaran yang tepat pada perusahaan berarti perusahaan telah memiliki daya saing didalam pasar. Kemampuan bersaing inilah yang akan menentukan omset penjualan dan profitabilitas yang akan diraih sehingga perusahaan dapat mempertahankan kelangsungan hidupnya.

Keberhasilan suatu strategi yang telah ditetapkan sangat ditentukan oleh seberapa besar tingkat kesesuaian strategi tersebut dengan perubahan lingkungan, persaingan, serta situasi perusahaan. Pada akhirnya perencanaan strategi yang 
meliputi analisis, perumusan, evaluasi sangat membantu perusahaan dalam menetapkan strategi pemasaran yang tepat.

b. Spesifikasi produk dan product differentiation

Setiap keputusan yang mengenai produk dalam aspek pemasaran ini akan mencangkup bentuk penawaran fisik, brand, kemasan, garansi, dan juga after sales service. Pengembangan produk ini bisa di lakukan, setelah mengetahui kebutuhan dan juga keinginan pasar. Bila masalah ini selesai, maka keputusan terkait dengan harga, distribusi, dan juga promosi, pun bisa langsung di ambil.

c. Analisa pasar dan peramalan permintaan

Analisa pasar adalah salah-satu langkah yang harus di lakukan dalam merencanakan strategi yang sesuai dengan kondisi pasar guna menangkap peluang apa saja yang ada dan lebih mengembangkan usaha. Umumnya analisa ini akan menghasilkan suatu pembaharuan dalam bentuk pemasaran, yaitu keuntungan yang bisa di dapat oleh pembeli bila membeli suatu produk.

d. Analisa competitor

Competitor adalah perusahaan lain yang memproduksi atau memasarkan barang atau jasa yang mempunyai kesamaan dengan produk yang anda tawarkan. Analisa competitor ini harus di lakukan dengan melakukan identifikasi pada kesempatan yang ada, ancaman, ataupun, ataupun persoalan strategis lainnya yang bisa muncul dari pergantian suasana bersaing yang lebih potensial.

Analisa competitor ini juga di lakukan untuk bisa mengukur perbedaan yang di miliki oleh competitor, baik itu dari sisi kualitas, produk harga, system pemasaran yang di terapkan, dan juga mengenai aspek pemasaran lainnya. 
e. Promosi

Promosi adalah ujung tombak utama dari aspek pemasaran dalam mengelola suatu bisnis. Promosi adalah upaya dari pihak penjual untuk menawarkan produk dagangannya pada pihak pembeli atau konsumen agar mau melakukan pembelian pada penjual. Selain itu, promosi juga adalah suatu informasi ataupun ajakan yang di lakukan secara satu arah dalam rangka memberikan suatu pengarahan pada orang ataupun kelompok agar mau melakukan sesuatu yang lebih mengarah pada pertukaran.

\section{Fungsi pemasaran}

a. Pengenalan produk

Pengenalan menjadi fungsi utama dari sebuah pemasaran yang di lakukan oleh perusahaan. Dengan adanya pemasaran, produk akan lebih mudah di kenal oleh pelanggan. Pemasaran harus menonjolkan keunngulan dari produk yang di pasarkan. Sehingga bisa lebih menarik perhatian di banding produk pesaing.

b. Riset

Riset memungkinkan pemasar untuk mendapatkan informasi yang tepat mengenai pasar target sebuah produk. Beberapa haal yang biasanya harus di riset adalah kepopuleran, usia, jenis kelamin, kebutuhan hingga keinginan dan lain sebagainya. Nantinya produk yang di produksi bisa di sesuaikan dengan apa yang sesuai dengan target pasarnya.

c. Distribusi

Dengan distribusi yang baik, akan memastikan bahwa produk dapat mudah di pindahkan dari lokasi produksi ke pasar yang luas menggunakan jalur darat, air, dan laut. Selain itu juga memastikan bahwa produk dapat dengan 
mudah di dapatkan oleh pelanggan. Sebagai pemasar juga harus merencanakan segala sesuatunya seperti armada, keuangan dalam proses distribusi.

d. Layanan purna jual

Dalam sebuah penjualan, layanan setelah penjualan memang sangat di butuhkan. Pemasar harus membantu pelanngan setelah mereka membeli produk. Misalnya, seperti produk mesin, pelanggan mungkin kesulitan ketika menemukan masalah pada mesin yang telah mereka beli. Tugas pemasar, memastikan dan membantu agar mesin itu berjalan dengan semestinya.

\section{Jenis-jenis pemasaran}

a. Branding

Branding adalah bentuk pemasaran yang memiliki fungsi sebagai iklan jangka panjang. Ini sangat membantu untuk membuat produk atau layanan menjadi lebih menarik dan terkenal. Branding sering kali menyertakan nama, slogan, dan logo.

b. Iklan siaran

Menggunakan radio media pemasaran adalah salah satu bentuk iklan berbayar yang paling umum. Pemasaran ke pelanngan sangat potensial ketika menggunakan radio karena pendengar radio benar-benar mendengarkan apa yang di ucapkan oleh penyiarnya. Selain itu, juga bisa mengunakan media tv untuk menjangkau pelanggan secara luas.

c. Multi-level marketing

Pemasaran dengan menggunakan multi-level marketing adalah bentuk penjualan langsung yang melibatkan banyak orang di mana perusahaan merekrut dan menjual produk-produknya. Multi-level marketing juga di sebut nework 
marketingkarena tenaga penjualan mendapatkan komisi dari produk yang mereka jual serta komisi penjualan dari jaringannya.

d. Internet atau online

Internet menjadi salah-satu media pemasaran yang paling di minati. Hamper semua orang pasti menggunakan internet sehingga pasarnya sangat luas.

Pemasaran dapat di lakukan dengan berbagai cara seperti menggunakan email website atau iklan.target pasarnya bisa di tentukan karena banyak penyedia jasa iklan yang memiliki fitur ini. 


\section{BAB 111}

PENUTUP

A. Kesimpulan

Pemasaran merupakan hal yang penting dalam sebuah bisnis, semakin baik strategi bisnis maka semakin cepat bisnis anda berkembang. Keputusan tentang penentuan pasar sasaran yang akan dilayani merupakan keputusan strategi bisnis yang paling menentukan. Pilihan strategi ini adalah tentang bagairnana bersaing dalarn setiap pasar produk yang diminati. Selain itu ada analisis penentuan posisi yang berguna dalarn mengestimasi tanggapan pasar, mengevaluasi persaingan dan preferensi pembeli.

B. Saran

Berdasarkan makalah di harapkan para pelaku bisnis atau usaha agar kiranya dapat melihat dan menetahui kondisi pasar sebelum membuat produk dan memasrkannya. Hal ini sangat penting di lakukan agar produk yang di pasarkan sesuai dengan kebutuhan pasar pada saat itu jangan sampai produk yang di tawarkan tidak laku karena ketidak sesuaian tadi. 


\section{DAFTAR PUSTAKA}

Agustin, N. K. Y., 2003. SEGMENTASI PASAR, PENENTUAN TARGET DAN PENETUAN POSISI. EkonomiManajemen-Akuntansi, 1(2), pp. 91-1 06.

Feti Fatimah, M. W. R. S., 2019. Pemetaan Pasar Dan Strategi Pemasaran Secara Islami. jurnal ekonomi, 15(2), pp. 337-354.

Husni, K., 2018. PENGARUH BAURAN PEMASARAN TEMPAT TERHADAP KEPUTUSAN PEMBELIAN NASABAH PT. BANK NAGARICABANG SITEBA PADANG. Jurnal Marketing, 1(1), pp. 28-34.

ibnuismail, 2021. accurate. [Online]

Available at: http://accurate.co.id

[Accessed sabtu 27 november 2021].

Lukitaningsih, A., 2013. PERKEMBANGAN KONSEP PEMASARAN: IMPLEMENTASI DAN IMPLIKASINYA. Jurnal MAKSIPRENEUR, 3(1), pp. 21-35.

Mardatila, A., 2020. merdeka.com. [Online]

Available at: http://m.merdeka.com

[Accessed sabtu 27 november 2021].

Nurjaman, K., 2018. Kewirausahaan Pemasaran (Entrepreneurial Marketing) pada Usaha Kecil. Jurnal KELOLA: Jurnal IImu Sosial, 1(2), pp. 143-158.

priharto, s., 2019. cpssoft. [Online]

Available at: http://cpssoft.com

[Accessed sabtu 27 november 2021]. 